\title{
Legal, environmental and technological bases of social shelters in Russia and in the republic of Mordovia
}

\author{
Elena Sergeevna Sergushina ${ }^{1,}$, Oleg Vladimirovich Kabanov ${ }^{1}$, and Valentina Alekseevna \\ Bogatyrskaya ${ }^{1}$ \\ ${ }^{1}$ National Research Ogarev Mordovia State University, 430005, Bolshevitskaya street 68, Saransk, \\ Republic of Mordovia, Russia
}

\begin{abstract}
The article briefly describes the current state of orphans who are in social shelters. The article considers the legal and technological bases of the activities of such institutions in the Russian Federation in the field of restoring child-parent relations. An example is given of the activities of the GKUSO RM " Republican Social Shelter for children and adolescents "Nadezhda" "(Republic of Mordovia). The structure and activities of the shelter, goals, objectives, technologies and project activities are analyzed in detail.
\end{abstract}

\section{Introduction}

Almost 20 years ago, our country, along with other States, adopted and ratified the UN Convention on the Rights of the Child. The adoption of this document marked the transition to a qualitatively new level of the state's attitude to the problem of children and childhood. The Convention declares the obligation for the States parties to "provide the child with such protection and care as is necessary for his well-being" (Part 1, Article 3). It does not forget orphans and children equated to them. 20 states: "A child who is temporarily or permanently deprived of his or her family environment or who, in his or her own best interests, cannot remain in such an environment is entitled to special protection and assistance provided by the State" [1]. The signing of this document places an additional responsibility on our society in relation to children deprived of parental attention, including in the framework of the activities of social shelters.

Children are a socio-demographic group of the population under the age of 18, with specific needs and interests, socio-psychological characteristics [2]. A social shelter is a social service institution that provides specialized services to children who find themselves in a difficult life situation and need emergency social assistance to ensure their temporary residence, social rehabilitation and further employment [3].

\section{Materials and methods}

\footnotetext{
*Corresponding author: sergushinaes@yandex.ru
} 
The current situation with orphans in social shelters in Russian society is not very unfavorable. First, the vast majority of children in social shelters are known to have parents, but they are usually deprived of their parental rights by the court or are subject to a court decision-making process. Secondly, the composition of minors in shelters is very complex in social and pedagogical terms and differs from that in orphanages or boarding schools, since:

- the vast majority of children have already become addicted to smoking, systematic alcohol consumption;

- most children are in a crisis or borderline state due to socio-psychological deprivation in the family, physical or sexual violence, school maladjustment;

- almost all children have chronic diseases;

- many children have never studied anywhere, they have not formed (or lost) basic social and household skills, experience of life in the family;

- many children have mental retardation, etc.

Third, the current uncertainty and instability of living conditions in our country is particularly reflected in the fate of this category of children. The experience of developed countries shows that market relations exacerbate the competition of the labor force, the victim of which is primarily young people with low professional qualifications. Natives of social shelters with their weak adaptive abilities and lack of support from the parent family in such conditions become the first candidates for outcasts [4]. Social protection of families and children in the Republic of Mordovia is undergoing a period of active modernization. The improvement of the situation of children is recognized as one of the main tasks. Building a modern model of providing social assistance to families and children is a complex and multifaceted process that requires an interdepartmental approach. Today, it involves legislative and executive authorities, State institutions, public institutions, organizations, and the scientific community. All of them say that the" center of gravity " of the new model of providing social assistance to families and children should fall on preventive work with families at risk [5]. Today, a whole complex of institutions is responsible for ensuring children's well-being: family, education, health care, and social protection. Such activities are carried out with the participation of government authorities, state and municipal services, professionals, business and mass media, charitable organizations and foundations. One of the subjects of this activity in the Republic of Mordovia is the State Institution of Social Services of the Republic of Mordovia " Republican Social Shelter for Children and Adolescents "Nadezhda ""(hereinafter referred to as " Republican Social Shelter for Children and Adolescents "Nadezhda"). The activities of the Republican Social Shelter for Children and Adolescents "Nadezhda "are directly related to the prevention and elimination of homelessness and neglect of minors in the region. According to the Federal Law of 24.06.1999. 120-FZ "About bases of system of prevention of neglect and offenses" [6] the facility works in partnership and in close contact with all authorities and institutions of the system of prevention (the Commission on minors ' Affairs, division of juvenile institutions, social protection, education, which are designed to solve problems of childhood. If the facts of improper performance of their duties by their parents are revealed, minors are sent to the social shelter "Nadezhda" for the time of deciding their future fate, and the bodies of the prevention system begin to work with the family [7].

The main purpose of the shelter is to provide emergency social assistance to minors who find themselves in a difficult life situation, to prevent neglect and homelessness. To date, the shelter "Nadezhda" is a whole built system that is designed to implement the social adaptation of the child to life in a healthy environment; to protect the legitimate rights and interests of the child; to restore or compensate for the social ties of children. The most important aspect of the shelter's activities is the search for ways to improve the forms of work with families to restore lost family ties and with children to prepare for family life. The main task of the institution is the social rehabilitation of recipients who find themselves in a difficult life 
situation, ensuring their temporary residence and maintenance, preventing neglect and homelessness of minors, as well as assisting the guardianship and guardianship authorities in the further placement of children left without parental care [8].

The objectives of the institution are:

- to provide emergency social assistance to recipients who find themselves in a difficult life situation, to prevent neglect and homelessness of minors;

- providing temporary residence of recipients for the period necessary to overcome a difficult life situation;

- providing social services to recipients in an accessible form and in accordance with their age and health status;

- identifying and analyzing the causes that contribute to the emergence of a difficult life situation for recipients;

- protection of the rights and legitimate interests of recipients [8]. The structure of the GKUSO RM " Republican Social Shelter for Children and Adolescents "Nadezhda" is shown in Figure 1.

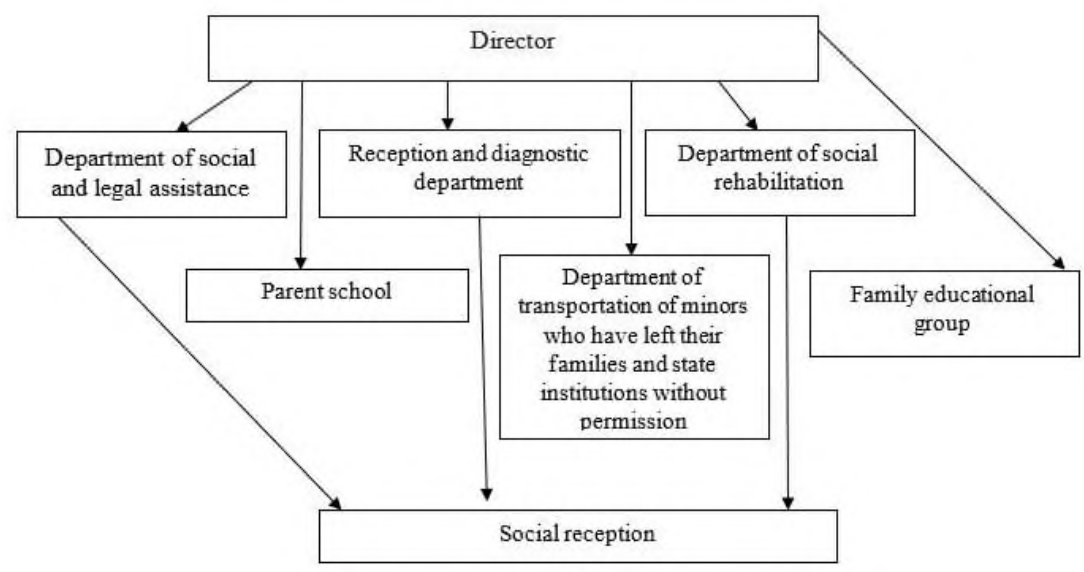

Fig. 1. Structure of GKUSO RM " Republican social shelter for children and adolescents "Nadezhda»»».

The actual problems that families address to the shelter (if possible, specify no more than 3 possible answers) are: socio-psychological - $30 \%$, socio-pedagogical- $23 \%$, socio-legal$18 \%$ (Figure 2) [5].

In connection with the new recommendations of the Ministry of social protection of population of the Republic of Mordovia for the implementation of the action Plan ("roadmap"), "improving the efficiency and quality of services in the field of social services of the Republic of Mordovia for 2013 - 2018," was introduced changes to the structure of all social protection institutions for minors. Effective forms of work used in the shelter " Nadezhda "in this direction are the activities of the" Parent School"," Social Reception", problem-making groups, the organization of project activities. Problem-creative groups, which are associations of teachers and specialists of the shelter, characterized by signs of joint activity, cohesion, are focused on the joint solution of socially significant, personaldeveloping and rehabilitation tasks for the successful socialization of minor children. The final result of the work of problem-creative groups is program and methodological materials, projects, creative works, participation in All-Russian competitions of children's creativity [9].

The main tasks of the parent school are: the association of parents, the coordination of their activities in the education of children, psychological and pedagogical support of the educational process carried out in families at risk. In addition to conversations, consultations, classes are held by specialists on the interaction of children and adults, on correcting mistakes 
in communication, on the prevention of various kinds of addictions [9]. The social reception is designed to provide timely, qualified advice and prompt assistance to minors and their parents.

Within the framework of this form of work, preventive and rehabilitative work is carried out to restore child-parent relations without placing the child in an institution: counseling, conversations, trainings, referrals to medical institutions, family therapy [10].

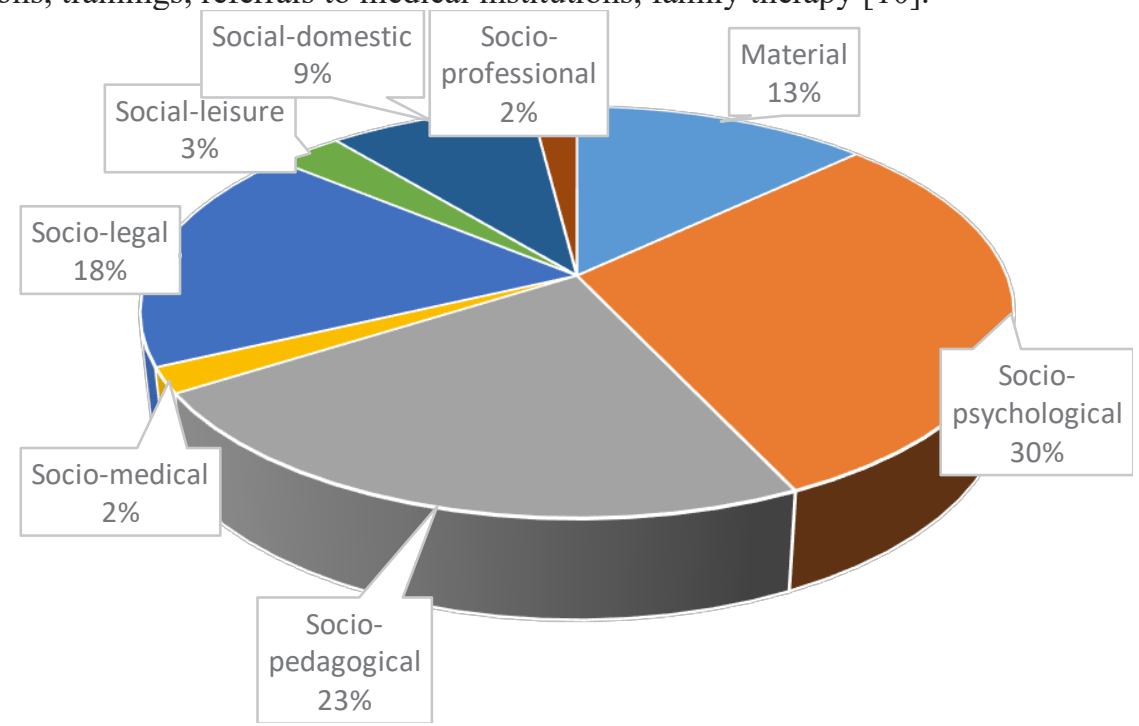

Fig. 2. The most urgent problems that families address in the shelter.

\section{Results}

Thus, at present, the structure of the Republican Social Shelter for Children and Adolescents "Nadezhda "allows for a continuous process of rehabilitation of the child and his immediate environment at the early stages of family problems. Among the main preventive measures that are carried out in the shelter when working to restore the family and child potential with the families of the pupils, the following were noted (if possible, specify all the appropriate answers) (table 1) [5]:

Table 1. Preventive measures carried out in the shelter when working to restore the family and child potential with the families of the pupils.

\begin{tabular}{|c|l|c|}
\hline $\begin{array}{c}\text { № } \\
\mathrm{p} / \mathrm{p}\end{array}$ & \multicolumn{1}{|c|}{ The responses of the experts } & $\begin{array}{c}\text { Number of } \\
\text { persons, \% }\end{array}$ \\
\hline 1 & $\begin{array}{l}\text { assistance (advice) in employment, registration of benefits, subsidies, } \\
\text { financial assistance in a crisis situation, etc. }\end{array}$ & 20 \\
\hline 2 & $\begin{array}{l}\text { instilling the skills of a healthy lifestyle, prevention of diseases, treatment } \\
\text { of alcohol dependence }\end{array}$ & 100 \\
\hline 3 & \begin{tabular}{l} 
instilling family values and traditions \\
\hline 4
\end{tabular} & $\begin{array}{l}\text { organization of psychological, legal, and pedagogical assistance, solving } \\
\text { problems of school maladjustment, diagnosis and correction of deviant } \\
\text { behavior }\end{array}$ \\
\hline 5 & $\begin{array}{l}\text { restore the old or building new, positive social relationships, facilitating } \\
\text { conflict resolution, harmonization of parent-child and marital } \\
\text { relationships }\end{array}$ & 100 \\
\hline
\end{tabular}


The obtained data allow us to note a wide range of technologies and measures used in the activities of the State Committee of the Republic of Moldova "Republican Social Shelter for Children and Adolescents "Nadezhda" to restore the family and child potential in the families of the orphanage's pupils. One of the technologies actively used by the shelter in the field of restoring child-parent relations is project activity. So, in 2010, the institution became a laureate of the contest "Business glory of Russia - 2010" on the implementation of the project "the road of life", which provides support pupils who have left the shelter walls. At the Russian Forum "Russian Innovations - Russian Capital" in the category "Social Innovation", an innovative technology of working with the family to preserve and restore family ties was presented, thanks to the implementation of which more than $91 \%$ of children were returned to their families. The institution is an experimental and methodological platform for social protection institutions and educational institutions of the Republic of Mordovia.

\section{Discussion}

The main ideas of the institution's work on the implementation of new models and technologies for working with families and children in difficult situations formed the basis of the Republican target program "The right of the child to the family" (2011-2013), the project of the United Russia party "Russia-every child is important" (2013 - present), the projects of the Fund for the Support of Children in Difficult Situations "City of Children City of Families" and "City of Equal Opportunities" (2011 - present) [9]. In 2009 and 2015. the institution became the winner of the republican contest "The best goods of Mordovia" in the category " Services to the population "("Goods and services for children") with the presentation of a Declaration of Quality to ensure a high level of provision of social services to children [9]. For more than 10 years, the institution successfully cooperates with the nonprofit public organization of the Republic of Mordovia "Hypnotherapy Club" Trust " and implements a unique program of hypnotherapy classes in the process of rehabilitation of minors in institutions of social and pedagogical support [11]. In 2015, the technology "Working with the case «was tested. It was recognized as the best author's development, which became the winner in the competition held by the Ministry of Social Protection of the Population of the Republic of Mordovia. As part of the implementation of this technology, an Interdepartmental Family Support Service was created as a body of interaction with specialists of the system for the prevention of neglect and delinquency. The institution was the first in the Republic of Mordovia among the institutions of social protection for minors that received Grant support from International and All-Russian Competitions [9]. The implementation of the project activity allows the shelter to provide psychological and pedagogical services to disabled children within the framework of the "Social Reception". The shelter also implemented projects that received a Grant from the Foundation for Support of Children in Difficult Situations: "Teach me to live" (social rehabilitation of disabled children and their integration into society, including in the conditions of summer and winter recreation, 2011), "Family: from crisis to success" (early prevention of family problems and social support for families, 2015) [11]. In 2016-2017. the institution has become a coexecutor of many socially significant projects.

\section{Conclusions}

The results of the use of new models and social technologies for family support of the Republican Social Shelter for Children and Adolescents "Nadezhda" were presented at the Public Council under the Ministry of Social Protection of the Population of the Republic of Mordovia. Thus, today the shelter is a whole built system that is designed to implement the 
social adaptation of the child to life in a healthy environment; protect the legitimate rights and interests of the child; restore or compensate for the social ties of children; ensure the safety and protection of the child from abuse. Currently, the institution actively integrates innovative mechanisms of medical, psychological, pedagogical and social technologies, which gives a stable positive dynamics, provides a comfortable, benevolent atmosphere for the life of each child. It is important not only to organize high-quality rehabilitation work with the families of our students, but also to prevent the child from entering a social protection institution for minors.

\section{References}

1. Convention on the Rights of the Child: official website [Electronic resource]. - Access mode: https://www.un.org/ru/_conv/conventions/childcon

2. E.S. Medvedeva, Dictionary of terms on the theory of social work: a methodological guide [Electronic resource]. - Access mode: https://clck.ru/NHgPi

3. Social services for the population. Procedure and conditions for providing social services to children: National Standard of the Russian Federation GOST R 54343-2011 from 01.07.2012 [Electronic resource]. - Access mode: http://docs.cntd.ru/document/gost-r54343-2011

4. E.N. Mikhailova, Children from social shelters: difficulties of adaptation to life in society, Social work in Russia: education and practice: collection of scientific works (Tomsk, February 27, 2009)

5. T.V. Barashikhina, Prevention of child and family problems in the framework of the implementation of new models and social technologies of family support, Social workthe phenomenon of a civilized society: Mat. VI Vseros. part-time scientific research.practical conf. with Intern. participation (Saransk, November 20, 2015)

6. On the basics of the system of prevention of neglect and offenses [Electronic resource]: Federal Law of 24.06.1999 g. 120-FZ / / Garant: [inform. - legal portal]. - [M., 2018]. Access mode: https://base.garant.ru/12116087/

7. T.V. Barashikhina, Russia is important for every child, Conceptual and applied aspects of social work with family and children in a multi-ethnic environment: mat. IV correspondence scientific research.- practical conf. with Intern. participation (Saransk, November 20, 2013)

8. Charter of the organization of the State Committee of the Republic of Moldova "Republican social Shelter for children and adolescents "Nadezhda" [Electronic resource]. - Access mode: http://rsp_nadezhda.soc13.ru/documents?type $=4$

9. Development program of the State Institution of the Republic of Moldova " Republican Social Shelter for Children and Adolescents "Nadezhda" for 2017-2020. [Electronic resource]. - Access mode: http://rsp_nadezhda.soc13.ru/doc?id=725

10. M.V. Larionova, Conceptual and applied aspects of social work with family and children in a multi-ethnic environment: mat. IV correspondence scientific research.- practical conf. with Intern. participation (Saransk, November 20, 2013)

11. GKUSO RM "Republican social shelter for children and adolescents "Nadezhda" [Electronic resource]: official website. - Access mode: http://rsp_nadezhda.soc13.ru/ 